\title{
Chronic Instability of Distal Radioulnar Joint
}

\section{Hyun-Dae Shin, Soo-Min Cha}

Department of Orthopaedic Surgery, Regional Rheumatoid and Degenerative Arthritis Center, Chungnam National University Hospital, Chungnam National University College of Medicine, Daejeon, Korea

Received: May 10, 2014

Accepted: June 2, 2014

Correspondence to: Hyun-Dae Shin Department of Orthopaedic Surgery, Regional Rheumatoid and Degenerative Arthritis Center, Chungnam National University Hospital, 266 Munhwa-ro, Jung-gu, Daejeon 301-721, Korea

TEL: +82-42-280-7340

FAX: +82-42-252-7098

E-mail: hyunsd@cnu.ac.kr

This is an Open Access article distributed under the terms of the Creative Commons Attribution Non-Commercial License (http://creativecommons.org/ licenses/by$\mathrm{nc} / 3.0 /$ ) which permits unrestricted noncommercial use, distribution, and reproduction in any medium, provided the original work is properly cited.
Chronic instability of distal radioulnar joint (DRUJ) can develop after injury such as fractures or dislocations, to the bony structures or to the soft tissue as like ligament, capsule. If proper treatment is not performed, normal biomechanics of DRUJ would be altered, thus arthritic joint with chronic functional impairment, pain resulted in. The proper treatments included several procedures for repair of the bony structures and recovery of realignment, various methods for soft tissue repair and reconstruction in unstable condition without bony structures destruction. Several salvage methods such as Darrach procedure, hemiresectional interposition arthroplasty, Sauve-Kapandji procedure, were recommended for the advanced arthritic DRUJ. Wide ulnar resection, onebone forearm procedure, prosthetic replacement for DRUJ were rarely indicated, but the a few long-term results were reported. Operative stabilization (repair or reconstruction) for each structure assumed as DRUJ instability, is essential and proper selection among the several salvage procedures for the advanced arthritis joint, is needed.

Keywords: Distal radioulnar joint, Instability, Ligament reconstruction, Salvage procedure

\section{서론}

원위 요척 관절의 만성 불안정은 대개 외상 후 발생한 골절, 탈구 등의 골성 요소의 손상 또는 인대, 관절막 등의 연부 조 직의 손상으로 유발된다 ${ }^{1-8}$. 이러한 불안정을 치료하지 않을 경우 원위 요척 관절의 정상 생역학의 변화를 초래하여 만성 기능 장애와 지속적 통증 발생, 악력의 감소 등의 결과가 초래 된다. 원위 요척 관절은 척골 두와 원위 요골의 S상 절흔(sigmoid notch)이 이루는 관절로, 매우 큰 회내, 회외전 운동이 일어나기 때문에 관절의 안정성은 대부분 연부 조직에 의존한 다 ${ }^{9-12}$. 특히, 전완의 회전 운동시 수장측 및 배측의 전이 (translation)가 동시에 일어나는 그 자체가 불안정한 구조물 이다. 사체 연구에서 4 가지 모양의 원위 요척 관절로 분류하 였으며 $42 \%$ 편평한 모양의 관절면이며 나머지에서 C형, $\mathrm{S}$ 형, ski slope형을 나타내는 것으로 보고하였다(Fig. 1). 또, 특이 점으로 사체의 $98 \%$ 에서 수장측의 골연골 변연부(volar osteocartilagenous lip)이 척골 두의 수장 측 탈구를 막는 안 정체로 작용하는 것으로 관찰되었다 ${ }^{13}$. 원위 요척 관절에 안정 성을 부여 하는 구조에는 원위 요척 관절의 관절막, 수장 및 배측 요척 인대, 삼각섬유연골 복합체, 척수근 신건, 척수근 인대, 골간막, 방형 회내근 등이 알려져 있다. 동적 안정체 (dynamic stabilizer) 및 정적 안정체(static stabilizer)로 구 

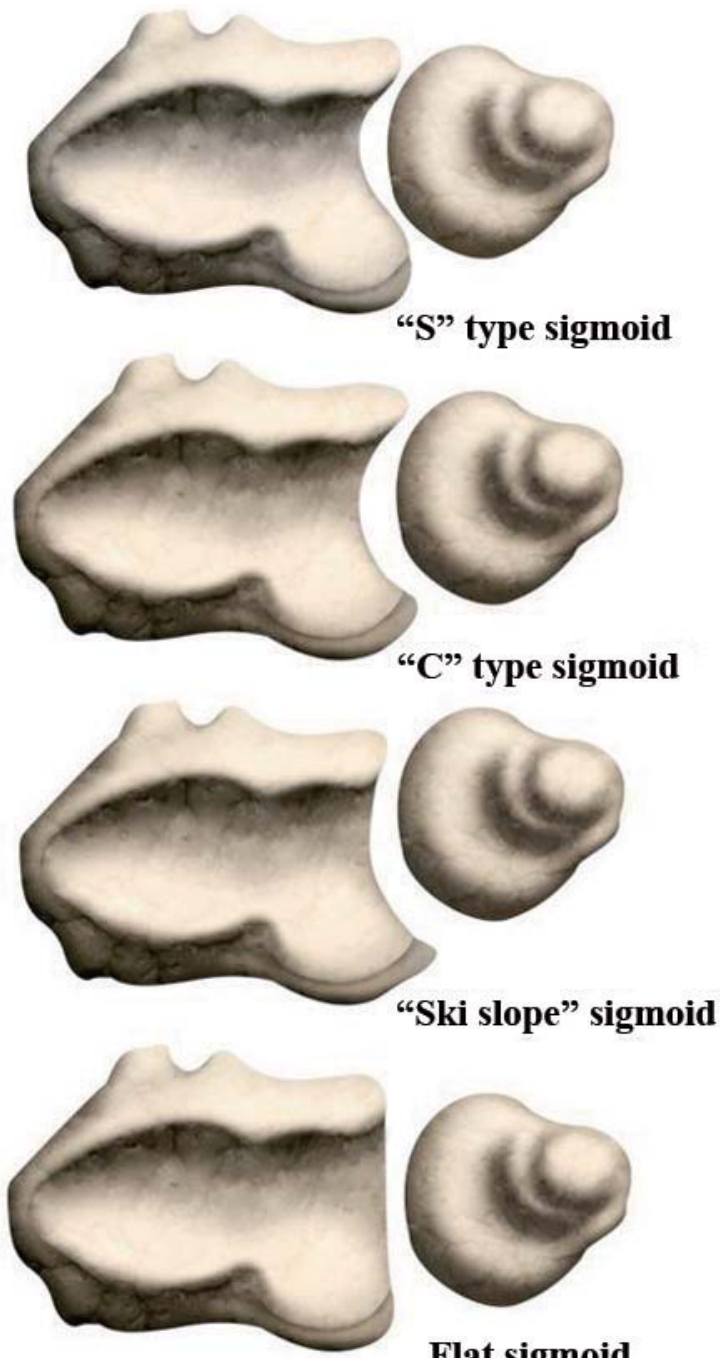

Flat sigmoid

Fig. 1. The four anatomic variations of the sigmoid notch.

분을 할 수 있으며 척수근 신근과 방형 회내근은 동적 안정체 로 관절막, 척수근 인대(ulnotriquetral ulnolunate ligament), 골간막, 삼각섬유연골 복합체는 정적 안정체로 구분할 수 있다. 또한, 정적 안정체 중 일차 안정체는 수장 및 배측 요 척 인대로 볼 수 있다. 이는 원위 요척 관절의 원위 변연부에 서 기시하여 삼각섬유연골 복합체 및 척 수근 관절 낭이 모이 는 곳에서 두꺼워 진다.

후방 전위의 정도가 $20^{\circ}$ 이상인 원위 요골 부정 유합은 원위 요척 관절의 $\mathrm{S}$ 상 절흔의 부조화(incongruity) 뿐만 아니라, 삼 각섬유연골 복합체의 염전(distortion), 원위 요척 관절의 불 안정과 모두 연관이 된다. 만성 불안정성은 원위 요골 골절과 흔히 동반되는데, 원위 요골의 단축이 있을 경우 상대적으로 척골 양성 변위(positive ulnar variance)가 발생하여 척측 수 근관절 통증의 원인이 된다.

\section{치료}

원위 요척 관절의 만성 불안정 치료 계획 수립에 있어 1) 전 방, 후방 및 다방향(multidirectional) 불안정으로 분류할 수 있는 불안정의 방향, 2) S상 절흔의 변연 결손(rim deficit)의 위치, 3) 절흔의 깊이, 4) 관절면 조화의 유지 여부, 5) 전완수근부의 정렬 상태, 6) 원위 요골의 부정 유합 존재 여부, 7) 척골 수근골의 충돌이 여부, 8) 척골 경상 돌기 기저부의 골절 유무, 9) 원위 요척 관절면의 연골 상태, 10) 관절의 안정성에 기여하는 원위 요척 관절 관절막, 수장 및 배측 요척 인대, 삼 각섬유연골 복합체, 척수근 신건의 건막 등의 약화 유무 등에 대한 면밀한 검사가 필요하다. 우선 비수술적 치료로서 전완 중립위에서 4-6주간의 부목 고정을 통해 약화된 연부 조직의 치유 또는 구축의 효과를 기대할 수 있다. 완전 고정을 할때는 주관절 상방까지 부목 고정을 시행할 수 있다. 또한, 동적 안 정체인 척수근 신근, 방형 회내근에 대한 강화 운동을 시행할 수도 있다. 그러나 이런 비수술적 방법들은 급성 손상, 아급성 또는 만성 손상 중 많은 활동력을 필요로 하지 않는 환자, 다 른 내과적 질환 등으로 수술이 어려운 환자, 소아 환자에서 적 용할 수 있다는 데 한계가 있다. 대개 수술적 치료를 선택하게 되며 관절의 퇴행성 병변이 없는 경우 연부 조직에 대한 복원/ 재건, 골성 구조물 정렬의 교정, 복원/재건 등의 수술적 치료 를 시행할 수 있다.

\section{골성 구조물의 부정 정렬에 대한 술기}

원위 요척 관절의 동적 불안정은 제 1,2 형으로 구분해 볼 수 있는데 1형(type I)의 경우는 비해리성 요골 부정 유합 (nondissociative radial malunion)으로 원위 요골의 골편의 후방 각형성이 존재함에도 요골-척골-수근골 등의 관계는 유 지되는 경우이다. 정확한 측면 단순 방사선 사진으로 요-척수근골 관계를 판단 할 수 있으며 전, 후방 원위 요척 관절 인 대는 정상으로 유지되는 경우로 와(fovea)를 중심으로 한 전완 의 회전도 정상이다. 교정 절골술로 $\mathrm{S}$ 상 절흔의 해부학적 복 원을 얻으면 원위 요척 관절의의 안정성과 정상 운동을 얻을 수 있다. 교정 절골술 후의 고정은 대개 $\mathrm{K}$-wire로 가능하나 후방 금속판, 골편 고정용 금속판 등으로 가능하며 쐐기 모양, 마름모꼴의 지주골 이식 등으로 각형성과 길이를 모두 회복할 수 있다. 각형성 뿐만 아니라 요척골 사이의 길이차도 고려해 야 하며 불일치가 있다면 동시에 교정해야 척골로 전달되는 과부하나 척골-수근골 사이의 충돌도 막을 수 있다. 원위 요 척 관절의 레벨을 맞추는 술식(leveling procedure)은 요골 연 
Hyun-Dae Shin, et al. Chronic Instability of Distal Radioulnar Joint

장, 척골 단축 또는 동시에 시행하는 방법이 있다. 척골의 단 순 단축의 경우 사선 절골을 통해 절골 부위의 지연 나사를 통 한 압박 후 금속판 고정이 우수한 유합율을 보인다. 수술 시 절골 후 최종 고정 전, 전완부의 회전 운동의 전체 범위에서 안정성과 정상 운동학을 얻었는지 확인을 요한다.

2형(type II)의 해리성 요골 부정 유합(dissociative radial malunion)의 경우, 요척 관절의 인대 손상이 발생하며 측면 단순 방사선 상에서 정상 정렬에서 벗어난 요골의 관절내 골 절편, 수근골, 척골 등의 비정상적 배열이 관찰된다. 원위 요 척 관절의 1,2 차 안정체 모두가 손상된 것으로, 척골에 대한 요골의 회전 축도 정상에서 벗어난 상태이며 손상 받은 연부 조직의 반흔이 생기는 경우 원위 요척 관절의 충돌(abutment)도 발생한다. 대개 회외전의 기계적 잠김이 발생하며 골 성 구조물들의 해부학적 복원이 치료의 우선이며 그 후 연부 조직의 복원/재건을 고려해야 한다. 제 1 형의 손상과 다른 점 은, 골성 구조물의 해부학적 정복만으로는 안정성과 정상의 운동학의 회복이 어렵다는 것이며 연부 조직에 대한 술식 등 을 반드시 시행해야 한다는 점이다. 척골 경상 돌기의 기저부 골절은 원위 요척 관절 인대의 심부, 척수근 인대들의 와 부착 부의 손상을 동반하여 불안정을 유발한다. 삼각섬유연골 복합 체 자체의 손상이나 약화가 없다면 급성, 및 아급성 손상 단계 에서 반드시 고정을 해야 하며 골절 부위는 척골의 피하 부분 을 통해 도달하는데, 배측 척골 신경, 척수근 신근의 건막의 손상이 되지 않도록 주의하여야 한다. 고정 방법은 먼저, 골편 의 크기를 감안하여 고정 과정 중 분쇄(fragmentation)가 되 지 않도록 조심하여 $\mathrm{K}$-wire ( \pm tension band suture), 유관 나사, 압박 나사, 핀 금속판(pin-plate), 소형 골편 금속판, 봉 합용 나사못(suture anchor) 등을 이용할 수 있다. 이렇듯 급 성, 아급성 손상에서의 기저부 골편 고정은 그 자체만으로 배 측 원위 요척골 인대의 안정성 회복에 충분하나 만성의 경우 는 골편 고정만으로는 구축된 연부 조직/약화된 인대에 대한 회복이 부족하다. 편평하거나 얕은 $\mathrm{S}$ 상 절흔의 경우 원위 요 척 관절의 불안정에 대한 연부 조직 재건의 결과가 다소 불량 하다. 전완부 회전 운동 시의 안정성은 회내전, 회외전에 대한 안정체들의 긴장력과 척골 두를 동심적으로(concentric) 잡을 수 있는 S상 절흔의 테두리(rim)의 짝힘(coupled joint reactive force)로 이뤄진다. 편평한 모양의 $\mathrm{S}$ 상 절흔에 대해 교정 골 성형술은(corrective osteoplasty) 단독 또는 연부 조직 재 건과 함께 시도해 볼 수 있는 술식으로 Wallwork와 Bain ${ }^{14}$ 에 의해 소개된 것으로 월상와(lunate fossa)의 바로 근위부와 $\mathrm{S}$ 상 절흔의 바로 근위 경계에 원위 요골의 관절면과 평행한 절 골을 가한 후 요골의 장축에 평행한 절골을 추가로 가해 경첩
형태의 골연골 피판을 척골측으로 들어올려 S상 절흔을 깊게 한다.

\section{연부 조직에 대한 술식}

요골 부정 유합과 같은 골성 병변이나 관절염의 소견이 없 는 만성 불안정에 대한 이상적 치료는 원위 요척 인대의 복원 이다. 원위 척골의 와에 매듭 고정을 통해 요척 인대의 지연 복원, 재부착을 시도할 수 있으나 만성적 약화가 있거나 손상 범위가 큰 경우 재건적 술기를 요한다.

외재적 재건 방법(extrinsic reconstruction)을 3가지로 구 분할 수 있으며 원위 요척 관절의 묶기(direct link, radioulnar tether), 척수근 굴근 슬링(flexor carpi ulnaris sling)을 이 용한 건 고정(ulnocarpal sling tenodesis), 전후방 원위 요척 인대 직접 재건으로 나눠 볼 수 있다. Fulkerson과 Watson" Hui와 Linscheid ${ }^{5}$, Tsai와 Stilwell ${ }^{6}$ 과 Boyes와 Bunnell 방 법 등의 다양한 외재적 방법들이 소개되었으나, 관절외의 조 여 묶는 술식(tethering)만으로 임상 증상을 호전 시키더라도 이는 비해부학적 복원이며 안정성과 와 정상 운동학을 다시 얻기에는 부족하다. Boyes와 Bunnell 방법 ${ }^{2}$, Hui와 Linscheid ${ }^{5}$ 방법은 척수근 굴근의 원위 기저 일부를 이용하여 수장측의 척수근 인대를 재건할 수 있는 술기로 척수근 굴근 과 관절의 불안정을 동시에 해결할 수 있는 술기이다(Fig. 2). 해부학적, 내재적 원위 요척 인대의 재건은 Scheker 등?, Johnston-Jones와 Sanders ${ }^{8}$, Adams와 Divelbiss ${ }^{15}$ 에 의해 소개되었으며, Scheker 등은 원위 요, 척골에 가한 드릴 홀 을 통해 건 이식편을 이용하여 후방의 원위 요척 인대를 재건 하였으며 Johnston-Jones와 Sanders'는 장장근(palmaris longus), 족척근(plantaris)을 이용하여 재건하였다. Adams

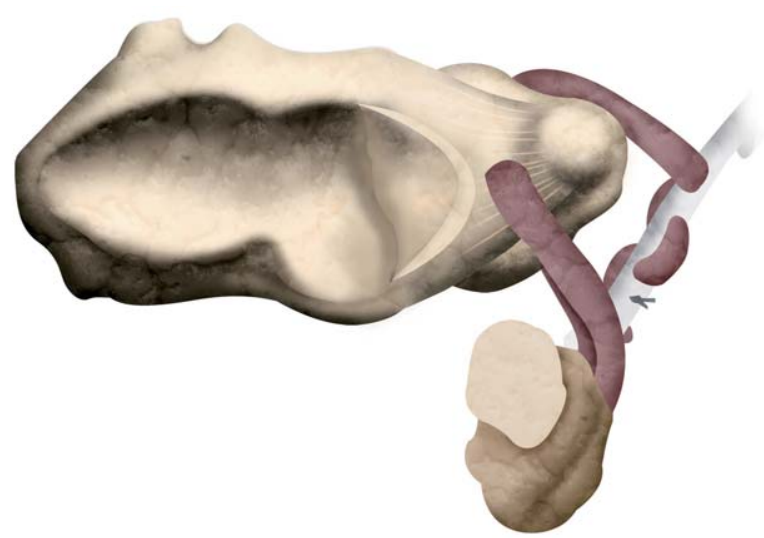

Fig. 2. Illustration of plication of the Flexor carpi ulnaris tendon graft onto its proximal limb. 
J Korean Soc Surg Hand Vol. 19, No. 2, June 2014

와 Divelbiss ${ }^{15}$ 에 의해 소개된 방법은 전, 후방 원위 요척 인대 모두를 재건하는 해부학적 재건의 개념으로 후방의 제 5,6 구 획으로 접근하여 삼각섬유연골 복합체 잔존물, 척골 경상 돌 기, 원위 요척 관절의 연골면을 관찰한 후 재건을 한다(Figs. $3,4)$. 삼각섬유연골 복합체 잔존물은 대개 복원할 수 없는 상 태이고 척수근 신근 건막(extensor carpi ulnaris tendon sheath)은 연골 복합체의 안정체 일부로 작용하도록 건막을 절개하지 않고 척골 구(ulnar groove)내에 보존하도록 한다. 불유합된 경상 돌기 기저부 골절은 제거하고 장장건, 족척근 (plantaris)를 이용하여 S상 절흔의 위치에 후방에서 전방으 로 가한 홀을 따라 건을 관통 시키며 fovea에서 척골 경부를 따라 가해진 구멍을 관통시킨다. 척골 경부를 각각 감싼 건을 조임으로써 재건된 전, 후방의 인대 및 와에서 적절한 장력을 얻게 된다. Adams와 Berger'는 12예의 환자에게 이 술기를 적용한 바(2예에서는 척골 단축술 동시에 시행), 1 년 추시에서 전 예에서 건측에 비해 평균 $80 \%$ 의 회외전, $84 \%$ 의 회내전, $85 \%$ 의 악력을 얻은 것으로 보고하였다.

\section{구제 술기}

만성 불안정, 외상후 관절 모두 원위 요척 관절의 퇴행성 관 절염을 유발한다. 관절염 존재 시 골성 구조물 및 연부 조직의 재건만으로는 지속적 통증 및 기능의 약화 등으로 술 후 결과 가 기대에 못 미친다. 구제 술기(salvage procedure)들은 이 러한 진행된 원위 요척 관절의 관절염 병변에 "불안정과 통증 을 유발하는 관절의 해소를 위해" 적응이 된다. 구제 술기에 속하는 것으로는 Darrach 술기, Bower의 반절제 개재 관절 성형술(hemiresectional interposition arthroplasty), Sauve-Kapandji 술기, 광범위 척골 절제술, 요척 유합을 통 한 단일 골 전완술, 인공 관절 치환술 등이 있다. 1912년 처음 소개된 Darrach 술식은 대개 상지의 많은 기능을 요하지 않 는 환자들에게 좋은 적응이 되며, 젊고 활동적인 환자에게는 다소 결과가 불량하다, ${ }^{9}$. 원위 요골의 $\mathrm{S}$ 상 절흔의 가장 근위 부의 1-2 cm 근위에서 절골, 절제를 하며 대개 이 부위가 방 형 회내근 부착 부위보다 근위이기 때문에 수렴 불안정(convergence instability)을 피할 수 있다. 삼각섬유연골 복합체 를 보존할 수 있는 술기로 볼 수 있으며 합병증으로는 잔존하 는 원위 골편의 불안정이 있을 수 있으며 대개 술전 불안정이 문제 되었던 경우 발생한다. Dingman'은 원위에서 절제된 척 골이 작을수록 골막내의 재형성과 연관되어 우수한 결과를 얻 었다고 보고하였다.

원위 척골단(distal ulnar stump) 안정을 위한 여러 술기들 이 보고되었으며 ${ }^{10}$, Breen과 Jupiter ${ }^{16}$ 는 척수근 신근 및 굴근 일부를 이용한 안정화 술식을 소개하였으며 Ruby 등믄 방형
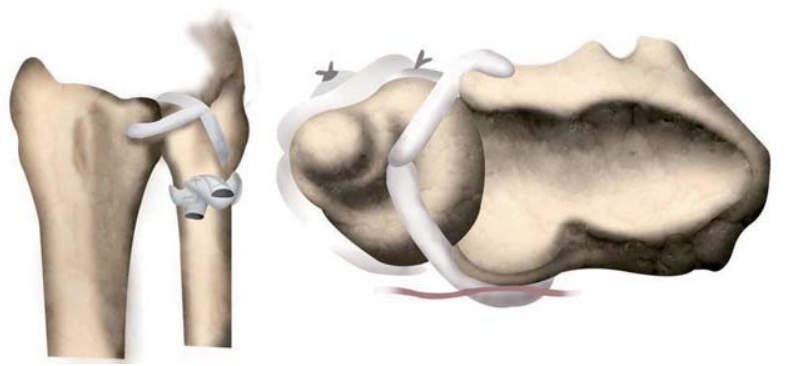

Fig. 4. Illustrations of passing the free tendon graft (palmaris longus) through the radial and ulnar bone tunnels and around the ulnar neck.
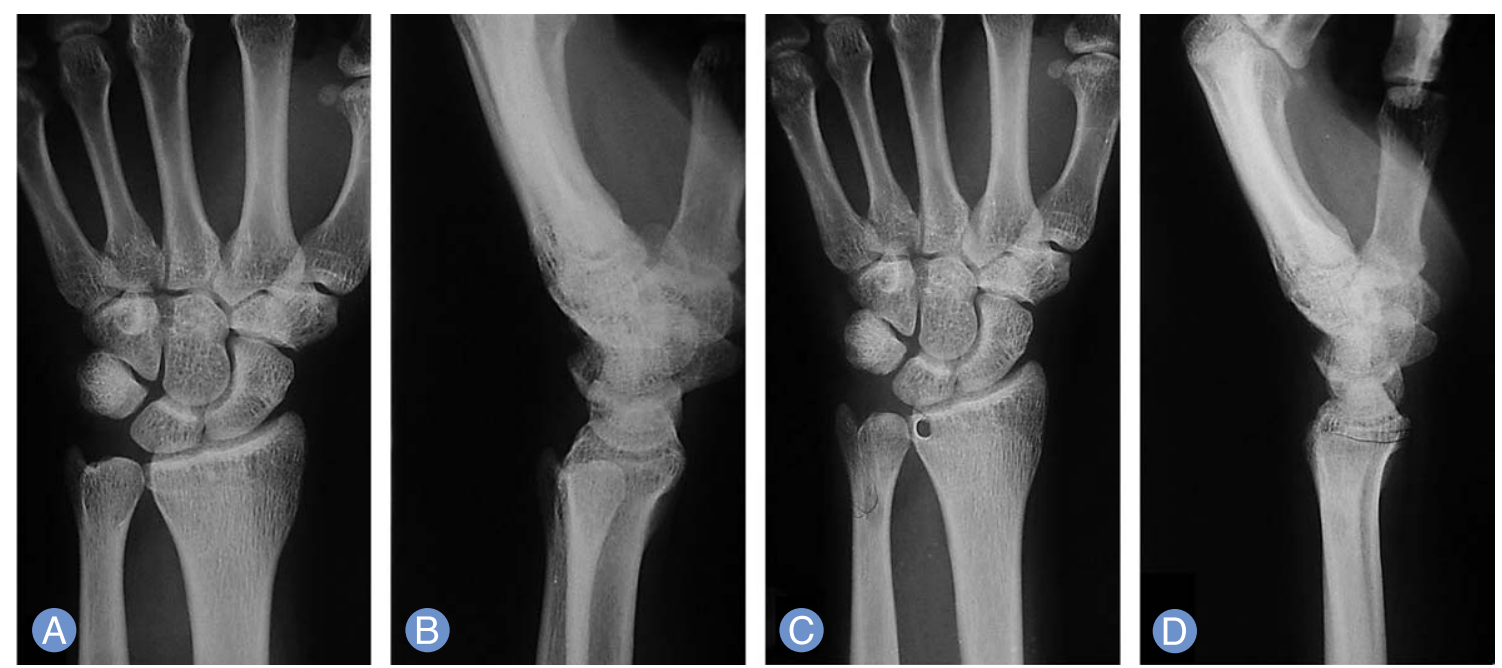

Fig. 3. (A, B) Preoperative radiographs of painful, unstable wrist. (C, D) 6 years follow-up radiographs after distal radioulnar joint reconstruction (Adam's technique). 
Hyun-Dae Shin, et al. Chronic Instability of Distal Radioulnar Joint

회내근을 이용한 술식을 소개하였다. Sotereanos 등른 원위 척골단의 수렴 불안정을 해결하기 위한 동종 이식물(allograft material)을 이용한 구제 술기를 소개하였다. 반절제 개재 관 절성형술은 Darrach 술식 후의 불안정 해결을 위해 고안되었 으며 척골 두에서 요측의 일부분 만을 비스듬히 절제하여 삼 각섬유연골 복합체의 와 부착 부위와 경상 돌기를 보존할 수 있으며 관절막과 방향 회내근을 개재 하여 사용할 수 있고 배 측의 관절막을 수장 측의 관절막에 고정하여 관절염에 유발되 는 기계적 통증의 완화에는 효과적이지만 원위 요척 관절 불 안정, 척골 충돌 증후군, 척수근 전이가 주된 문제인 경우 결 과가 다소 불확실하다. 유사한 술식으로 Watson과 Gabuzda ${ }^{17}$ 에 의해 소개된 "matched distal ulna resection" 술기가 있으며 이는 삼각섬유연골 복합체 부착 부위와, 척수 근 인대를 희생하나 노출된 해면골과 그 주변을 둘러싼 골막 등과의 연부 조직과의 치유를 통해 안정성을 도모한다.

Sauve-Kapandji 술식은 원위 척골 절제의 대안으로 대두 된 술기로 증상을 유발하는 원위 요척 관절을 유합시키는 것 과 보다 근위에 가관절을 만들어 전완부 회전 운동을 보존하 는 것이 근간이다. Darrach 술식을 시행했을 때의 단점인 척 측 수근골에 대한 척골의 지지력 약화, 절제된 근위 척골 원위 단에서의 동통을 동반한 불안정성, 수부의 전체적인 악력의 감소 등이 대두되었고 생역학적 연구 결과에 의하면 수근 관 절의 척측 지주가 소실되는 것은 수근 관절의 안정성의 저해
요소로 작용하는 것으로 알려져 있어 수근 관절의 척측 지주 를 보존하여 수근 관절의 기능이나 안정을 도모하는 것이 장 점이다(Fig. 5). Goncalves ${ }^{18}$ 는 22 명의 환자를 대상으로 한 결 과 Darrach 술식에 비해 우수한 결과를 얻은 것으로 보고하 였으며, Taleisnik ${ }^{19}$ 는 37예를 대상으로 시행한 결과 통증 완 화와 전완부 회전 운동의 회복에 효과가 큰 반면 합병증은 적 은 우수한 결과를 보고하였다. 또한, 이 술식은 원위 요척 관 절의 불안정만이 주된 경우는 오히려 금기라고 기술하였다.

광범위 척골 절제는 대개 종양의 치료에 적용하는 술기였으 나 Wolfe 등은 원위 $1 / 3$ 에서 절제를 할 경우는 저명한 불안 정 없이 가능하다고 주장하였다. 척수근 전이는 드물지만 광 범위 절제 후 불안정 및 요척골의 수렴 불안정에 기인하는 것 으로 알려져 있다. 척골 절제 후의 안정성은 골간막에 의해 유 지되기 때문에 골간막의 손상이 동반되거나 기왕력으로 존재 한다면 광범위 척골 절제는 금기이다. Wolfe 등 20 의 보고에 의 하면 12 예 중 2 예의 불안정 및 요척골의 수렴을 제외하고, 평 균 관절 범위 및 악력의 75\%-90\%을 회복하였다.

요척골 유합을 통한 단일 골 전완술(one-bone forearm)은 원위 요척 관절의 불안정 및 관절염의 가장 궁극의 구제 술기 로 볼 수 있다. 다른 여러 술기에도 치료가 안되는 불안정 및 퇴행성 병변에서 고려할 수 있으며 원위 요척 관절의 가동성 은 불안정을 해소하기 위해 기능을 없애는 개념이다. 자가 골 이식을 이용한 금속판을 이용한 유합, 근위 요골 및 원위 척
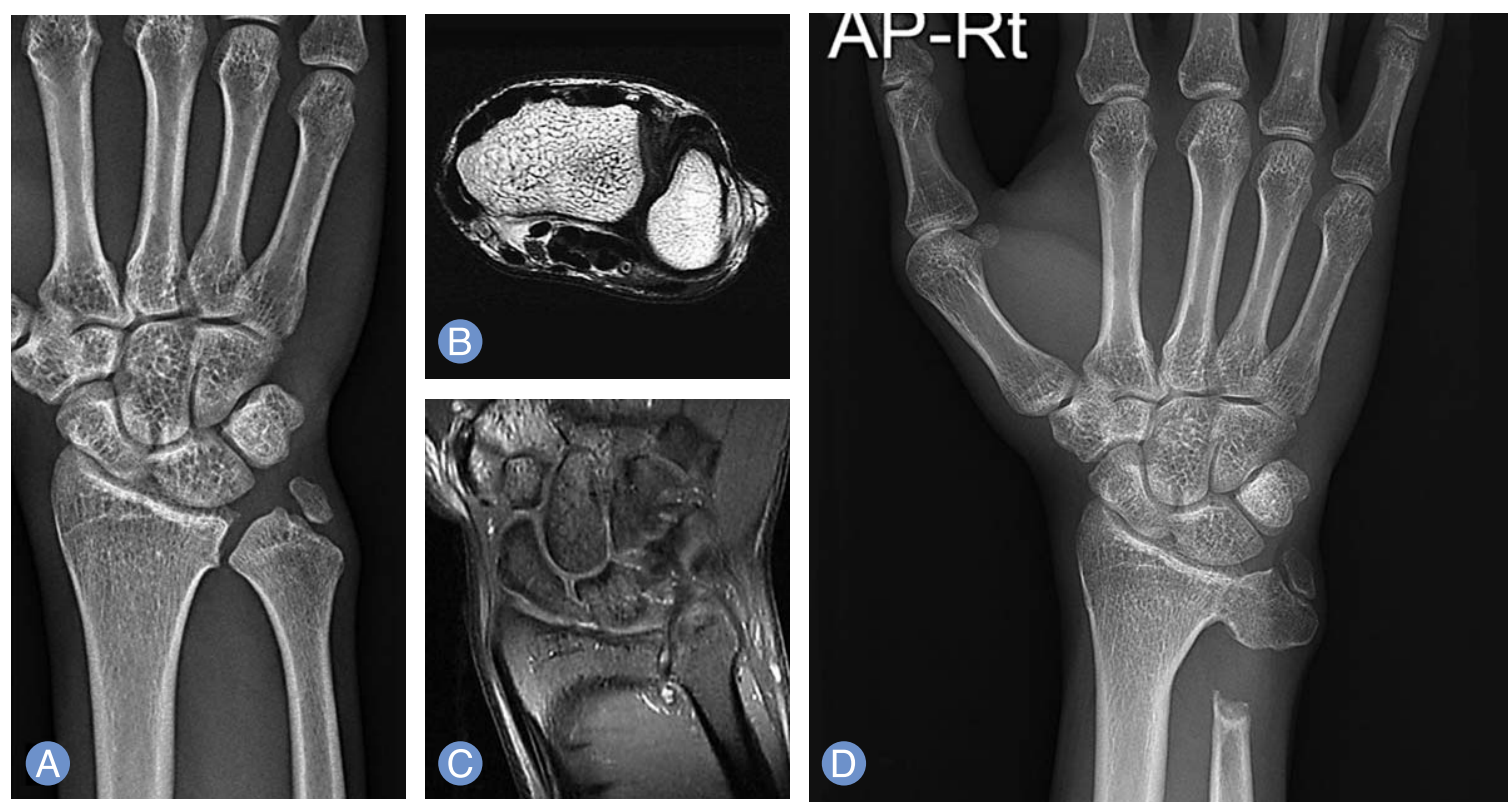

Fig. 5. (A,) A 45-year-old man with painful, unstable wrist during 2 years. Incongruency in distal radioulnar joint (DRUJ) and mild degenerative lesion in sigmoid notch were seen. (B) Volar subluxed ulnar head was definitive in axial view of DRUJ. (C) Chronic triangular fibrocartilage complex wear and irregularity of articular surface of DRUJ was seen in magnetic resonance imaging. (D) Two years follow-up radiograph after Sauve-Kapandji procecure. 
골을 제거한 상태에서 요골의 척골로의 전이 등을 통해 단일 골 전완부를 만들며 고정 위치는 중립 회전위나 약간의 회내 전위로 하여 일상 생활이나 개인 위생을 도모하도록 한다. Peterson 등은 불유합률이 30\%에 이르며 50\%에서 여러 합 병증이 동반되는 술식으로 신중히 시행할 것을 기술하였다.

\section{퇴행성 병변}

원위 요척 관절의 퇴행성 병변은 만성 불안정 또는 원위 요 골의 외상 후 관절염의 큰 두 가지 원인으로 악화, 진행된다. 심한 병변을 지닌 환자들은 오히려 소염제 등의 약물치료, 운 동 제한, 생활 방식의 변화 등과 같은 일시적인 비수술적 방법 으로 통증의 완화를 기대할 수 있다. 열치료, 초음파 등을 이 용한 물리 치료부터 영상 증폭 장치하의 스테로이드 주입 등 도 일시적으로 효과를 가져다 줄 수 있다. 수술적 치료는 상기 대로 Darrach 술식, 척골 단축술, Sauve-Kapandji 술식, 반 절제 개재 관절 성형술, 단일 골 전완 술식, 인공 관절 치환술 등이 있으며 특히, 척골 단축술은 원위 요척 관절의 퇴행성 병 변이 있는 환자에서 접촉면을 변화 시킬 수 있는 점이 특징으 로 Scheker와 Severo ${ }^{21}$ 는 32 명의 환자 중 18 예에서 우수한 결 과를 얻었다. Darrach 술식은 고령의, 비활동적인 환자에게 만 적용해야 하고 Breen과 Jupiter ${ }^{16}$ 의 척수근 신근을 이용한 안정화 술식을 겸해야 한다. 궁극의 구제 술기는 단일 골 전완 술식이지만 매우 드문 경우에만 그 적응이 된다. 인공 관절 치 환술은 원위 요척 관절의 불안정에 얼마나 큰 도움이 될지는 아직 밝혀진 바가 없으나 물리적 지지, 부하 전달에는 다소 효 과가 있을 것으로 판단된다. 최근에 고안된 내고정물은 삼각 섬유연골 복합체의 고정 및 척수근 신근 건막을 위한 부분까 지 있으며 S상 절흔의 인공물도 개발되고 있다. 그러나 이들 의 내구성에 대한 장기적 결과에 대한 보고는 없으며 척골 치 환물 삽입과 연부 조직 재건 술기에 비해 어떠한 장점이 존재 하는가에 대한 보고도 없다. 척골 두 치환물은 19예에서 시행 한 후 2 년 추시에서 통증 점수의 $50 \%$ 의 감소, 악력의 $16 \%$ 의 증가를 보였으며, 전완 회전의 호전은 없었지만, 안정된 수근 관절을 얻은 결과를 보였다. Scheker 등 22 은 요, 척골 사이의 일부 전이 운동이 가능한 ball and socket형의 원위 요척 관 절 전치환술 시행 후 평균 15 개월 추시에서 23 명의 환자에서 통증의 완전 소실 및 전완의 회전 운동의 저명한 회복을 얻었 다. 평균 5.9년의 추시에서 31 명의 환자에서 이와 유사한 결과 가 지속되었으며 내구성에 대한 보다 장기 추시가 필요할 것 으로 기술하였다.

\section{결론}

원위 요척 관절의 문제는 흔하지만, 대개 과소 평가 되는 경 우가 많다. 가장 중요한 해부학적 특징은 S상 절흔의 곡률 반 경이 척골 두의 곡률 반경보다 크다는 것이다. 즉, 결과적으로 회내전, 회외전시 전이 운동이 존재하는 불안정한 관절이다. 최근에 원위 요척 관절의 생역학에 대한 이해가 이뤄졌으며 현재까지의 견해는 1) 수장측의 원위 요척 인대가 전완부의 어 떠한 위치에서든, 배부로의 전이에 대해 끌어 담는 안정체 (containing stabilizer) 역할을 하며, 2) 배측의 원위 요척 인 대가 전완부의 회내전 위치에서 수장부로의 전이에 대해 역시 끌어 담는 안정체의 역할을 한다는 것이다. 또한, 자기공명영 상의 기술적 발전으로 급성 원위 요척 관절의 손상은 삼각섬 유연골 복합체의 손상이며 수술적 복원을 필요로 하고, 만성 의 손상에서는 수장측 및 배측의 원위 요척 인대의 정상적 복 원이 불가능하며 대개 재건을 요한다는 영상 의학적 근거가 명확해졌다.

원위 요척 관절의 퇴행성 관절염에 대한 다양한 수술적 술 기들이 소개되었으며 특히 인공 관절 치환술의 초기 결과는 양호한 것으로 판단되나 사실, 장기 추시는 아직 보고된 바가 없다. 궁극의 구제 술기는 결국 단일 골 전완부 술식이며 전완 부를 부동의 구조물로 만드는 것이다.

\section{REFERENCES}

1. Adams BD, Berger RA. An anatomic reconstruction of the distal radioulnar ligaments for posttraumatic distal radioulnar joint instability. J Hand Surg Am. 2002;27: 243-51.

2. Petersen MS, Adams BD. Biomechanical evaluation of distal radioulnar reconstructions. J Hand Surg Am. 1993;18:328-34.

3. Peterson CA 2nd, Maki S, Wood MB. Clinical results of the one-bone forearm. J Hand Surg Am. 1995;20:60918.

4. Fulkerson JP, Watson HK. Congenital anterior subluxation of the distal ulna. A case report. Clin Orthop Relat Res. 1978;(131):179-82.

5. Hui FC, Linscheid RL. Ulnotriquetral augmentation tenodesis: a reconstructive procedure for dorsal subluxation of the distal radioulnar joint. J Hand Surg Am. 1982;7:230-6.

6. Tsai TM, Stilwell JH. Repair of chronic subluxation of 
the distal radioulnar joint (ulnar dorsal) using flexor carpi ulnaris tendon. J Hand Surg Br. 1984;9:289-94.

7. Scheker LR, Belliappa PP, Acosta R, German DS. Reconstruction of the dorsal ligament of the triangular fibrocartilage complex. J Hand Surg Br. 1994;19:310-8.

8. Johnston-Jones K, Sanders WE. Posttraumatic radioulnar instability: treatment by anatomic reconstruction of the volar and dorsal radioulnar ligaments. Orthop Trans. 1995-1996;19:832.

9. Dingman PV. Resection of the distal end of the ulna (Darrach operation); an end result study of twenty four cases. J Bone Joint Surg Am. 1952;34 A:893-900.

10. Leslie BM, Carlson G, Ruby LK. Results of extensor carpi ulnaris tenodesis in the rheumatoid wrist undergoing a distal ulnar excision. J Hand Surg Am. 1990;15:547-51.

11. Ruby LK, Ferenz CC, Dell PC. The pronator quadratus interposition transfer: an adjunct to resection arthroplasty of the distal radioulnar joint. J Hand Surg Am. 1996;21:60-5.

12. Sotereanos DG, Gobel F, Vardakas DG, Sarris I. An allograft salvage technique for failure of the Darrach procedure: a report of four cases. J Hand Surg Br. 2002;27: 317-21.

13. Tolat AR, Stanley JK, Trail IA. A cadaveric study of the anatomy and stability of the distal radioulnar joint in the coronal and transverse planes. J Hand Surg Br.
1996;21:587-94.

14. Wallwork NA, Bain GI. Sigmoid notch osteoplasty for chronic volar instability of the distal radioulnar joint: a case report. J Hand Surg Am. 2001;26:454-9.

15. Adams BD, Divelbiss BJ. Reconstruction of the posttraumatic unstable distal radioulnar joint. Orthop Clin North Am. 2001;32:353-63.

16. Breen TF, Jupiter JB. Extensor carpi ulnaris and flexor carpi ulnaris tenodesis of the unstable distal ulna. J Hand Surg Am. 1989;14:612-7.

17. Watson HK, Gabuzda GM. Matched distal ulna resection for posttraumatic disorders of the distal radioulnar joint. J Hand Surg Am. 1992;17:724-30.

18. Goncalves D. Correction of disorders of the distal radioulnar joint by artificial pseudarthrosis of the ulna. J Bone Joint Surg Br. 1974;56:462-4.

19. Taleisnik J. The Sauve-Kapandji procedure. Clin Orthop Relat Res. 1992;(275):110-23.

20. Wolfe SW, Mih AD, Hotchkiss RN, Culp RW, Keifhaber TR, Nagle DJ. Wide excision of the distal ulna: a multicenter case study. J Hand Surg Am. 1998;23:222-8.

21. Scheker LR, Severo A. Ulnar shortening for the treatment of early post-traumatic osteoarthritis at the distal radioulnar joint. J Hand Surg Br. 2001;26:41-4.

22. Scheker LR, Babb BA, Killion PE. Distal ulnar prosthetic replacement. Orthop Clin North Am. 2001;32:365-76. 


\section{원위 요척 관절의 만성 불안정}

\section{신현대 · 차수민}

충남대학교 의학전문대학원 정형외과학교실

원위 요척 관절의 만성 불안정은 골절, 탈구 등으로 인한 골성 구조물 손상 또는 인대, 관절막 등의 연부 조직의 손상으 로 유발되며 적절한 치료가 이루어 지지 않으면 원위 요척 관절의 정상 생역학의 변화가 초래하여 만성 기능 장애, 통증 을 유발하는 관절염의 단계로 진행을 하게 된다. 적절한 치료로는 골성 구조물에 대한 복원, 정열의 회복을 위한 여러 술기가 있으며 골성 구조물의 손상이 크지 않은 연부 조직 손상에 의한 불안정의 경우 역시 여러 연부 조직 복원 및 재 건의 방법을 이용한다. 원위 요척 관절의 정상 관절 연골의 파괴로 진행되면 관절에 대한 여러 구제술을 동원하게 되는 데 Darrach 술기, 반절제 개재 관절성형술, Sauve-Kapandji 술기 등이 대표적이다. 드물게 광범위 척골 절제술, 요 척 유합을 통한 단일 골 전완술, 인공 관절 치환술 등도 적응이 되는 경우가 있으나 장기 결과에 대해서는 아직 보고된 바가 없다. 원위 요척 관절의 불안정 존재 시에는 불안정의 원인이 되는 구조물에 대한 복원, 재건 등의 수술적 치료를 통해 안정화 시키는 것이 중요하며 관절염 진행 시에는 가장 적합한 구제술을 선택해야 한다.

색인단어: 원위 요척 관절, 불안정, 인대 재건술, 구제술

접수일 2014년 5월 10일

게재확정일 2014년 6월 2일

교신저자 신현대

대전광역시 중구 문화로 266 권역

충남대학교 의학전문대학원 정형외과학교실, 권역 류마티스 및 퇴행성 관절염센터 정형외과

TEL 042-280-7340 FAX 042-252-7098

E-mail hyunsd@cnu.ac.kr 